\title{
DIPLOMAȚIA ECONOMICĂ A CHINEI ÎN EUROPA: INIŢIATIVA „17+1” ȘI IMPLICAȚII PENTRU SECURITATEA FLANCULUI ESTIC AL NATO
}

Tudor CHERHAT *

Această lucrare susține că Republica Populară Chineză a aplicat o formă de diplomație economică în Europa Centrală și de Est, pentru a-și extinde influența politică regională. Folosind Inițiativa , 17+1 ", China a încercat să ofere privilegii financiare statelor membre pentru ca acestea să devină ulterior dependente de viziunile politico-economice ale Beijingului. In pofida ingrijorării Uniunii Europene, rezultatele proiectului nu au fost cele așteptate, existând mari îndoieli cu privire la viitorul Inițiativei. Acestea au fost confirmate de poziția NATO, care a considerat că demersurile chineze nu reprezintă o problemă de securitate pentru flancul estic al Alianței.

Cuvinte-cheie: China; diplomație economică; Europa Centrală și de Est; Inițiativa ,17+1"; flancul estic al NATO.

\section{Introducere}

De-a lungul ultimului deceniu, Republica Populară Chineză a dezvoltat o strategie globală bazată pe diplomație economică, folosindu-și capacitățile financiare pentru a încerca să-și extindă influența în mai multe țări. În acest scop, au fost create mai multe cadre de dezvoltare bilaterale și multilaterale, inclusiv în centrul și estul Europei, unde China a stabilit o rețea economică cunoscută sub

* Tudor CHERHAT este doctorand în domeniul Relații internaționale și studii europene la Facultatea de Istorie și Filosofie din cadrul Universității „Babeș-Bolyai”, Cluj-Napoca. E-mail: tudor_cherhat@yahoo.com 
numele de Inițiativa $17+1$ (anterior $16+1$ ). Fiind parte a marelui proiect chinezesc Inițiativa ,Centura și drumul” (Belt and Road Initiative - BRI), aceasta a urmărit să stimuleze influența regională chineză în detrimentul NATO și al UE.

Luând în calcul aceste considerente, prezentul articol ilustrează evoluția Inițiativei $17+1$ și analizează implicațiile politice și de securitate pentru flancul estic al NATO. Astfel, vom identifica în ce măsură diplomația economică a Chinei servește ca instrument analitic pentru înțelegerea intențiilor sale geostrategice. Prima secțiune examinează politica externă a Chinei dintr-o perspectivă economică, așa cum este prezentată în literatura de specialitate existentă. A doua parte este dedicată inițiativei chineze din Europa Centrală și de Est (CEE) și explorează rezultatul acestui acord multilateral. Ultima parte evaluează provocările geopolitice ale strategiei chineze și oferă o perspectivă a viitoarelor dileme de securitate ale NATO la frontiera sa estică.

\section{Dezbateri teoretice privind diplomația economică a Chinei}

Există numeroase studii academice care au analizat politica externă chineză din perspectivă economică, accentul fiind pus pe modul în care China se va integra în sistemul internațional, odată ce va deveni o putere economică majoră. În acest sens, Joseph Nye de la Universitatea Harvard a definit soft power ca fiind capacitatea unui stat de a-și impune viziunea politică prin atractivitate, afirmând că ,atunci când o țară convinge alte țări să își dorească ceea ce aceasta își dorește s-ar putea numi putere de influențare sau soft, spre deosebire de puterea hard prin care li se impune să facă ceea ce aceasta dorește". ${ }^{1}$ Ipoteza lui Nye a devenit populară în mediul academic chinez la începutul anilor 2000, deoarece era un mod convenabil prin care China putea arăta lumii că a realizat o tranziție ideologică paşnică. Ca atare, numărul publicațiilor științifice pe această temă a crescut considerabil, prefigurând o competiție Est-Vest, pentru a consolida filosofia chineză. ${ }^{2}$ Termenul a devenit notoriu și la nivel oficial, fiind folosit constant de liderii chinezi - chiar și actualul președinte Xi Jinping a declarat că mesajul Chinei poate fi mai ușor de înțeles prin conceptul de soft power. ${ }^{3}$

$\mathrm{Cu}$ toate acestea, alți cercetători s-au străduit să înțeleagă modul în care China încearcă să-şi proiecteze dezvoltarea paşnică într-o strategie globală. De exemplu, Niall Ferguson și Ernest Wilson au considerat că nu se poate face o distincție clară între o

\footnotetext{
${ }^{1}$ Joseph S. Nye, „The Changing Nature of World Power”, în Political Science Quarterly, vol. 105, nr. 2, vara 1990, pp. 181-182.

${ }^{2}$ Hongyi Lai, „Introduction: the soft power concept and a rising China”, în Hongyi Lai; Yiyi Lu, China's Soft Power and International Relations, Routledge, New York, 2012, pp. 2-3 și 5-6.

${ }^{3}$ Ibidem, pp. 11-12; David Shambaugh, „China's Soft-Power Push: The Search for Respect”, în Foreign Affairs, vol. 94, nr. 4, 2015, p. 99.
} 
strategie bazată pe soft power și una axată de hard power, deoarece puterea militară este direct proporțională cu capacitățile economice. Prin urmare, capacitățile soft power nu pot îndeplini singure obiectivele strategice ale unui stat. ${ }^{4}$ Acest aspect a condus la ideea potrivit căreia China încearcă să sumarizeze conceptul de soft power ca o incluziune treptată a principiilor socialiste în monopolul capitalismului occidental.

Dezbaterile privind dinamica politicii externe s-au îndreptat apoi către apariția noilor concepte teoretice, precum diplomația economică interne au devenit tema centrală a guvernului chinez după moartea lui Mao Zedong, China a încercat să îmbunătățească competitivitatea internațională a țării, iar strategia sa a început să fie analizată din perspectiva diplomației economice. În acest sens, Evan Medeiros a observat că instrumente financiare, precum schimbul de bunuri sau accesul pe piețele globale, au devenit variabile elementare pentru scopurile diplomatice ale Chinei. ${ }^{5}$ Andreas Fuchs a concluzionat că Beijingul preferă ca relațiile economice să fie precedate de legături politice puternice. Descoperirile sale empirice sugerează că liderii chinezi acordă atenție problemelor politice și diplomatice atunci când vine vorba de parteneriate economice, ceea ce se datorează faptului că aceștia urmăresc obținerea unor beneficii financiare consistente în detrimentul unor motive cu substrat altruist. ${ }^{6}$ Shuxiu Zhang a explicat modul în care liderii chinezi au reformat diplomația economică pentru a servi intereselor proprii, renunțând la diplomația lor tradițională bazată pe ideologie, pe care au clasificat-o ca fiind ineficientă în raport cu extinderea parteneriatelor economice. În prezent, China este conștientă de beneficiile politice care pot fi obținute din influența economică, reușind să-și îmbunătățească considerabil relațiile cu actori importanți, precum UE sau SUA. ${ }^{7}$

$\mathrm{Au}$ existat de asemenea cercetători care au observat cum China își exportă modelul economic diferit, în funcție de nivelul de dezvoltare al țărilor țintă. Pentru statele dezvoltate, guvernul chinez marșează pe investiții și diplomație culturală, în timp ce în cazul celor aflate în curs de dezvoltare încearcă să implementeze programe economice la scară largă, pentru a-și proiecta influența politică. ${ }^{8}$ Alții au acuzat

\footnotetext{
4 Niall Ferguson, „Think Again: Power”, Foreign Policy, 3 noiembrie 2009, URL: https:// foreignpolicy.com/2009/11/03/think-again-power, accesat la 20.02.2021; Ernest J. Wilson, „Hard Power, Soft Power, Smart Power", în The Annals of the American Academy of Political and Social Science, vol. 616, 2008, p. 114 și 117.

5 Evan Medeiros, China's International Behavior: Activism, Opportunities, and Diversification, RAND Corporation, Santa Monica, 2009, p. 61.

${ }^{6}$ Andreas Fuchs, China's Economic Diplomacy and the Politics-Trade Nexus, Discussion Paper Series, nr. 609, Alfred Weber Institute, University of Heidelberg, 2016, pp. 3, 5 și 7-8.

${ }^{7}$ Shuxiu Zhang, Chinese Economic Diplomacy: Decision-making actors and processes, Routledge, New York, 2016, pp. 10 și 12-13.

${ }^{8}$ Nilgün Eliküçük Yildirim, Mesut Aslan, „China’s Charm Defensive: Image Protection by Acquiring Mass Entertainment”, în Pacific Focus, vol. XXXV, nr. 1, 2020, pp. 141-142 și 145-146.
} 
Beijingul că exercită o formă de imperialism prin extragerea resurselor naturale din țările subdezvoltate și promovarea proiectelor economice inechitabile. ${ }^{9}$

Cercetări privind modul în care China își poate impune influența economică pot fi găsite și în sfera academică chineză. Încă din anii ' 90 , s-a încercat formularea unei strategii naționale bazate pe diplomația economică, studiile concentrându-se pe subiecte, precum geopolitica și geoeconomia, și pe examinarea modalităților prin care Beijingul își poate maximiza beneficiile economice și politice. ${ }^{10}$ Această tendință a fost menținută până în zilele noastre, semn că declinul economic internațional al Chinei a rămas o problemă majoră pentru liderii chinezi. De exemplu, Yong Deng consideră că extinderea influenței economice este esențială pentru ca statul chinez să fie recunoscut ca un jucător puternic și responsabil pe scena internațională și pentru a-și menține stabilitatea internă. ${ }^{11}$ Wang Yiwei face o comparație între diferențele cu privire la percepția puterii în Occident și în Orient și susține că este de datoria liderilor chinezi să își exporte propriul model de dezvoltare către civilizațiile occidentale, pentru a-și consolida imaginea unei puteri benigne. ${ }^{12}$ Opiniile sale sunt împărtăşite de Luo Jianbo, care consideră că un stat este recunoscut cu adevărat ca putere globală numai atunci când își exportă propriile politici economice. ${ }^{13}$ Zhen Binxi merge mai departe și consideră că diplomația economică funcționează într-un cadru mai larg, încapsulând chiar și caracteristici militare sau culturale, atât timp cât promovează câștiguri economice. ${ }^{14}$

În ceea ce privește inițiativele economice ale Chinei în Europa, observatorii s-au străduit să identifice inferențe cauzale între dorința guvernului chinez de a face investiții masive în mai multe regiuni ale lumii și contextul geopolitic actual. Deși este clar că inițiativele economice ale unui stat conțin automat unele stimulente politice, dezbaterea a perpetuat două curente majore de opinie: posibilitatea ca proiectele Chinei să urmărească cu preponderență beneficii economice de tip câștigcâștig și suspiciuni cu privire la agenda politică secretă a Beijingului. De exemplu, Richard Turcsanyi și Eva Kachilkova au sugerat că Belt and Road Initiative (BRI) și

\footnotetext{
${ }^{9}$ Yang Yao, „Chinese Approach to Economic Diplomacy”, în John G. Ikenberry, Wang Jisi, Zhu Feng, America, China and the Struggle for World Order: Ideas, Traditions, Historical Legacies, and Global Visions, Palgrave Macmillan, New York, 2015, p. 161.

${ }^{10}$ Jeremy Garlick, „China's Economic Diplomacy in Central and Eastern Europe: A Case of Offensive Mercantilism?”, în Europe-Asia Studies, vol. 71, nr. 8, 2019, p. 4.

${ }^{11}$ Yong Deng, „The New Hard Realities: 'Soft Power' and China in Transition”, în Li Mingjiang (ed.), Soft Power: China's Emerging Strategy in International Politics, Lexington Books, Lanham, 2009, p. 64.

12 Yiwei Wang, „Public Diplomacy and the Rise of Chinese Soft Power," în The Annals of the American Academy of Political and Social Science, vol. 616, 2008, pp. 262-263.

${ }^{13}$ Nilgün Eliküçük Yildirim, Mesut Aslan, op. cit., 2020, p. 143.

${ }^{14}$ Timothy R. Heath, „China's Evolving Approach to Economic Diplomacy”, în Asia Policy, vol. 22, 2016, p. 163.
} 
„17+1" reprezintă o modalitate economică convenabilă pentru obținerea de capital politic, în special prin mass-media ${ }^{15}$, în timp ce Francois Godement și Abigail Vasselier au susținut că proiectele respective fac parte din marea strategie a Chinei de slăbire a UE prin tactica „,dezbină și cucerește”. ${ }^{16}$ Această ultimă opinie a fost împărtășită și de Angela Stanzel, care a considerat că membrii inițiativei (11 țări UE și 5 țări din afara UE) au fost selectați în mod deliberat pentru a submina politicile comunitare. ${ }^{17} \mathrm{Au}$ existat, de asemenea, voci care au împărtăşit ideea conform căreia principalele riscuri sunt reprezentate mai degrabă de impasuri economice și juridice, decât de aspecte politice, și pot include restricții asupra investițiilor străine, reglementărilor antitrust sau prevederilor de mediu. ${ }^{18}$

Se poate observa, așadar, că interesul Chinei pentru exportul propriului model economic conține atât inserții politice, cât și strategice. Dobândirea influenței internaționale este un proces lent care necesită, pe lângă parteneriate economice puternice, un climat politic și diplomatic favorabil. Astfel, inițiativele chineze trebuie analizate în funcție de capacitatea lor de a conduce la un posibil sistem de alianțe politice sau ideologice favorabile Chinei. În acest sens, este necesar un studiu aprofundat al inițiativei „17+1” pentru a extrage modele distinctive ale abordării chineze față de CEE.

\section{2. „Ofensiva" economică a Chinei pe plan internațional: de la BRI la „17+1”}

Odată cu încheierea erei maoiste, China a urmat o strategie axată pe reforme interne menită să îi stimuleze creșterea economică, guvernul concentrându-se, în primul rând, pe extinderea exporturilor și absorbția investițiilor străine directe. Primele semne de îmbunătățire au apărut în anii '80, după ce Deng Xiaoping a devenit liderul suprem al Partidului Comunist Chinez, iar faimoasa sa teorie a socialismului cu caracteristici chinezești un reper al noilor reforme socio-economice. Drept urmare, toți succesorii săi au continuat într-o oarecare măsură aceste reforme și au subliniat importanța menținerii ascensiunii economice a Chinei, în contextul unui nou concept de securitate. ${ }^{19}$

\footnotetext{
${ }^{15}$ Richard Q. Turcsanyi, Eva Kachlikova, ,The BRI and China's Soft Power in Europe: Why Chinese Narratives (Initially) Won", în Journal of Current Chinese Affairs, vol. 49, nr. 1, 2020, pp. 72-73.

${ }^{16}$ Francois Godement, Abigael Vasselier, China at the Gates: A New Power Audit of EU-China Relations, European Council on Foreign Relations, London, 2017, pp. 64-65.

${ }_{17}$ Angela Stanzel, China's Investment in Influence: The Future of 16+1 Cooperation, European Council on Foreign Relations, London, 2016, p. 2.

${ }^{18}$ Baker McKenzie, Belt \& Road: Opportunity \& Risk. The prospects and perils of China's New Silk Road, Silk Road Associates, 2017, pp. 22-24.

${ }^{19}$ Mădălina Virginia Antonescu, ,The New Chinese Security Concept and the "Peaceful Rise of China" as two basic pillars of the contemporary Chinese Foreign Policy", în Polis, vol. 3, nr. 1(7), 2015, pp. 59-62.
} 
După patru decenii, China a reușit să devină a doua cea mai puternică economie din lume, conform PIB-ului, și cea mai mare, având în vedere paritatea puterii de cumpărare, cu șanse mari de a depăşi SUA în viitorul apropiat. De asemenea, acest model de guvernanță economică orientat spre exterior a transformat China într-un actor global dispus să se implice mai intens în dezvoltarea relațiilor internaționale. Criza financiară din 2008 a fost oportunitatea ideală pentru Beijing de a include piața europeană în politica de tip ,going out”. Principala țintă a investițiilor străine directe chineze au fost proiectele de infrastructură inițiate prin acorduri bilaterale. ${ }^{20}$

Totodată, China a început să demareze inițiative economice proprii și să preia roluri de conducere în organizațiile internaționale. Pentru a-și demonstra abordarea proactivă, Beijingul s-a angajat în mai multe proiecte multilaterale, cum ar fi Parteneriatul Economic Cuprinzător Regional (Regional Comprehensive Economic Partnership - RCEP), Zona de liber schimb China-ASEAN sau ASEAN Plus Trei. Guvernul chinez a reușit chiar să creeze Banca Asiatică de Investiții în Infrastructură, o instituție financiară multilaterală cu sediul la Beijing, al cărei scop principal este îmbunătătirea misiunii de susținere socio-economică. ${ }^{21}$

Proiectul de referință însă a fost reprezentat de Inițiativa „,Centura și drumul” (Belt and Road Initiative - BRI), cunoscută anterior sub titulatura de „O centură, un drum" (One Belt One Road). BRI urmărește să consolideze diplomația economică a Chinei, promovând dezvoltarea infrastructurii și integrarea financiară pe tot globul, și se concentrează în principal pe extinderea comunicațiilor rutiere, feroviare și maritime, având potențialul de a deveni cea mai mare platformă de cooperare economică din lume. Proiectul a fost propus de liderul chinez, Xi Jinping, în 2013, și s-a estimat că va costa aproximativ 4-8 trilioane de dolari, fiind cea mai mare inițiativă economică contemporană. De asemenea, BRI a fost integrat, în 2017, în Constituția Chinei. ${ }^{22}$

După cum sugerează numele său, proiectul BRI dorește să conecteze economiile din estul Asiei cu cele din Europa și să ofere noi perspective de dezvoltare țărilor din Orientul Mijlociu și din nord-estul Africii. Este alcătuit dintr-un coridor terestru care include țări din centrul și vestul Asiei, Orientului Mijlociu și Europei. De asemenea, conține o rută maritimă care pornește din zonele costiere chineze și străbate Marea Chinei de Sud, Golful Bengal, Marea Arabiei și Marea Roșie, până în regiunea Adriatică. Ca atare, a fost prezentat de președintele chinez ca un proiect

${ }^{20}$ Philippe Le Corre, „Chinese Investments in European Countries: Experiences and Lessons for the „Belt and Road” Initiative”, în Maximilian Mayer (ed.), Rethinking the Silk Road, Palgrave Macmilan, Singapore, 2018, pp. 162-163.

${ }^{21}$ Hideo Ohashi, ,The Belt and Road Initiative (BRI) in the context of China's opening-up policy”, în Journal of Contemporary East Asia Studies, vol. 7, nr. 2, 2019, p. 92.

${ }^{22}$ Ibidem, p. 86. 
gigantic, care dorește să devină noul „Drum al Mătăsii”. ${ }^{23}$

Pe lângă componenta comercială, BRI conține și un substrat geopolitic, esențial pentru Beijing. Implementarea sa poate modifica semnificativ dinamica relațiilor Chinei cu Europa, Federația Rusă și SUA, având în vedere că un eventual succes al proiectului ar atrage numeroase economii emergente către sfera de influență chineză. ${ }^{24}$ De asemenea, iniţiativa vizează îmbunătătirea imaginii internaţionale a Chinei, ca urmare a disponibilității acesteia de a investi masiv pe piețele occidentale.

$\mathrm{Nu}$ în ultimul rând, proiectul BRI constituie un reper de factură domestică pentru Partidul Comunist Chinez. Economia chineză a cunoscut o contracție constantă după criza financiară din 2008, nereușind să mai înregistreze creșteri anuale de peste $7 \%$. Printre cauze se regăsesc populația îmbătrânită, creșterea costurilor forței de muncă și supraproducția din sectorul manufacturier. ${ }^{25}$ Aceste considerente pot periclita imaginea și legitimitatea internă a Partidului Comunist Chinez, care a fost perceput în ultimele trei decenii ca un model de stabilitate și modernizare economică, în special pentru clasa mijlocie chineză și pentru sferele de influență din jurul partidului. ${ }^{26}$

În pofida optimismului liderilor chinezi însă, au existat mai multe voci care au pus la îndoială aplicabilitatea proiectului ca urmare a numărului consistent de actori guvernamentali necesari. Au fost ridicate, de asemenea, numeroase întrebări cu privire la mijloacele concrete de implementare a proiectului și la perspectiva ca BRI să reprezinte doar un instrument pentru retorică politică. Alte voci au corelat inițiativa chineză cu politica neocolonială, ca urmare a disponibilității de a accepta acorduri cu state recunoscute pentru nivelul lor de corupție și pentru abuzurile împotriva drepturilor omului. În general, guvernul chinez urmărește o strategie de achiziție a resurselor naturale în schimbul realizării de produse și, ca atare, încurajează investițiile străine ale companiilor de stat chinezești în paralel cu creșterea independenței energetice. ${ }^{27}$ Totodată, inițiativa Chinei a fost catalogată ca reprezentând un,,împrumut capcană”, din cauza faptului că încorporează numeroase aranjamente politice. Oficialii SUA au atras atenția asupra vulnerabilităților strategice pe care le generează proiectul chinez în Europa și, în principal, în zona

\footnotetext{
${ }^{23}$ Zhao Minghao, ,,The Belt and Road Initiative and its Implications for China-Europe Relations”, în The International Spectator, vol. 51, nr. 4, 2016, p. 109.

${ }^{24}$ Ibidem.

${ }^{25}$ Ibidem, p. 110.

${ }^{26}$ Linda Glawe, Helmut Wagner, The People's Republic of China in the Middle-Income Trap?, Asian Development Bank Institute Working Paper, nr. 749, iunie 2017, pp. 12-15; Ruixue Jia, Masayuki Kudamatsu, David Seim, „Political Selection in China: The Complementary Roles of Connections and Performance", în Journal of the European Economic Association, vol. 13, nr. 4, august 2015, p. 666.

${ }^{27}$ Yang Yao, op. cit., 2015, pp. 181-182.
} 


\section{Balcanilor. $^{28}$}

Având în vedere că BRI a fost conceput ca un proiect global și că Europa este o piață strategică majoră, guvernul chinez a dezvoltat în acest sens un format de cooperare economică regională cunoscut sub numele de Cooperare intre China și țările Europei Centrale și de Est sau Inițiativa ,17+1". Formatul a fost stabilit în 2012 și include 16 țări (Albania, Bosnia și Herțegovina, Bulgaria, Cehia, Croația, Estonia, Letonia, Lituania, Macedonia de Nord, Muntenegru, Polonia, România, Serbia, Slovacia, Slovenia și Ungaria), fiind extins, în 2019, la 17 țări (Grecia). ${ }^{29}$

Conform prezentării oficiale, Inițiativa își propune să consolideze cooperarea economică între China și CEE, prin îmbunătăţirea sectorului de afaceri și a altor domenii financiare practice, organizarea de întâlniri la nivel oficial, coordonarea forurilor comerciale și implementarea rezultatelor obținute. ${ }^{30}$ De asemenea, formatul „17+1” este proiectat să îmbunătățească cooperarea în segmentele de transport și infrastructură, deoarece reprezintă un proiect complementar BRI. În acest sens, cele două iniţiative au fost promovate intens de liderii chinezi drept pilonii unui parteneriat sustenabil între China și Europa. ${ }^{31}$

Începând cu 2012, în fiecare an are loc un summit în care sunt analizate nivelul de implementare a proiectului și viabilitatea investițiilor viitoare. În 2021 a fost organizat un summit virtual, în care președintele Xi Jinping a oferit asigurări că toate părțile implicate vor împărtăși beneficiile acestei cooperări. ${ }^{32}$ Pe parcursul ultimului deceniu, China a investit peste 15 miliarde de dolari în infrastructură, energie, comunicații și transporturi, printre cele mai importante obiective numărându-se construcția de autostrăzi în Serbia, Ungaria, Muntenegru și Cehia, alături de exploatarea petrolului în Albania. ${ }^{33}$ Astfel, este ușor să identificăm un

${ }^{28}$ Karen P. Y. Lai, Shaun Lin, James D. Sidaway, „Financing the Belt and Road Initiative (BRI): research agendas beyond the "dept-trap" discourse", în Eurasian Geography and Economics, vol. 61, nr. 2, 2020, p. 110.

$29 * * *$, Embassies of CEE Countries to China, Cooperation between China and Central and Eastern European Countries, 2021, URL: http://www.china-ceec.org/eng/lj_5/zgzzdo16gsg/t1410687.htm, accesat la 24.02.2021.

$30 * * *$, Introduction of the Secretariat for Cooperation between China and Central and Eastern European Countries, Cooperation between China and Central and Eastern European Countries, 2013, URL: http://www.china-ceec.org/eng/msc_1/mscjj/t1411097.htm, accesat la 24.02.2021.

$31 * * *,, 16+1$ ” mechanism set to bolster China-Europe ties, Cooperation between China and Central and Eastern European Countries, 2018, URL: http://www.china-ceec.org/eng/zdogjhz_1/t1575579. htm, accesat la 24.02.2021; Astrid Pepermans, ,China's 16+1 and Belt and Road Initiative in Central and Eastern Europe: economic and political influence at a cheap price”, în Journal of Contemporary Central and Eastern Europe, vol. 26, nr. 2-3, 2018, p. 184.

$32 * * *$, „Full Text: Keynote Speech by Chinese President Xi Jinping at the China-CEEC Summit", în China Daily, 9 februarie 2021, URL: https://www.chinadaily.com.cn/a/202102/09/ WS6022920ba31024ad0baa8699.html, accesat la 26.02.2021.

${ }^{33}$ Jeremy Garlick, op. cit., 2019, p. 18. 
„model” concentrat pe dezvoltarea infrastructurii, achiziționarea de active strategice și promovarea unor linii mari de credit de către guvernul chinez.

Apariția proiectului „17+1” a confirmat rolul pivotal pe care relațiile comerciale sino-europene îl dețin în politica externă chineză. La momentul actual, Uniunea Europeană este principalul partener al Chinei, în timp ce statul chinez este al doilea partener comercial al UE, după SUA. ${ }^{34}$ De asemenea, nu există niciun conflict de natură geopolitică între cele două entități, care să nu permită dezvoltarea parteneriatului. Inițiativa a fost abordată cu optimism și de liderii din Europa central-estică, care au perceput-o ca pe o oportunitate de dezvoltare a infrastructurii și de intensificare a exporturilor către China. ${ }^{35}$ Regiunea CEE a rămas deficitară în ceea ce privește rețeaua drumurilor de mare viteză, fiind necesare investiții de aproximativ 615 miliarde de dolari pentru a ajunge la nivelul infrastructurilor din vestul continentului, și se confruntă cu un deficit comercial negativ în raport cu China. În acest context, proiectul „17+1" a fost privit și ca o modalitate de diminuare a acestui dezechilibru. ${ }^{36}$

\section{Evoluția Inițiativei „17+1” și implicațiile strategice pentru flancul estic al NATO}

Deși formatul „17+1” a fost configurat drept o iniţiativă economică, a început să fie văzut mai mult o declarație politică din partea Chinei, deoarece toți membrii, cu excepția Greciei, proveneau din vechiul bloc comunist. Drept urmare, posibilitatea extinderii influenței politice a Beijingului în regiunea CEE a ridicat problema securității flancului estic al NATO. Preocupările partizanilor euroatlantici au fost justificate, având în vedere că strategia Chinei a ilustrat o serie de acțiuni care au vizat extinderea pârghiilor sale politice.

În primul rând, analiza investiţiilor chinezești a evidențiat faptul că $70 \%$ dintre acestea erau destinate țărilor din afara UE, în ciuda faptului că doar cinci dintre cele 17 țări nu fac parte din UE, iar PIB-ul lor combinat reprezintă doar $6 \%$ din grup. ${ }^{37}$ În al doilea rând, investițiile chinezești au vizat țările cu cele mai înalte niveluri de corupție, potrivit Transparency International..$^{38} \mathrm{Nu}$ în ultimul rând, analizele au arătat că, la fel ca în cazul Chinei, curentele naționaliste sunt prezente în conștiința

\footnotetext{
$34 * * *$, Countries and regions: China, European Commission, 22 aprilie 2021, URL: https://ec.europa. eu/trade/policy/countries-and-regions/countries/china, accesat la 10.05.2021.

${ }^{35}$ Astrid Pepermans, op. cit., 2018, p. 185.

${ }^{36}$ Ibidem.

${ }^{37}$ Jonathan E. Hillman, Maesea McCalpin, "Will China's "16+1" Format Divide Europe?", Center for Strategic and International Studies, URL: https://www.csis.org/analysis/will-chinas-161-formatdivide-europe, accesat la 26.02.2021.

$38 * * *$, „Corruption Perceptions Index”, Transparency International, URL: https://www.transparency. org/en/cpi/2020/index/nzl, accesat la 26.02.2021.
} 
colectivă a țărilor din CEE. Serbia este un exemplu elocvent din cauza numeroaselor sale conflicte etnice din anii ' 90 , asemănătoare tensiunilor dintre China și regiunile sale autonome. În același timp, bombardarea ambasadei chineze din Belgrad din aceeași perioadă a marcat un moment care a consolidat relațiile diplomatice dintre cele două țări. La rândul său, Ungaria a anunțat, în 2011, o politică de deschidere către Est, pentru a crește oportunitățile economice și pentru a reduce dependența de Occident. Și Polonia și Cehia au promovat o formă de naționalism economic, bazată pe intervenționism și conservatorism. ${ }^{39}$

Toate aceste aspecte pot fi privite și din perspectiva unei oportunități strategice pentru guvernul chinez de a-și reînnoi conexiunile istorice cu regiunea CEE. $\mathrm{Au}$ apărut temeri la nivelul oficialilor de la Bruxelles cu privire la modul în care Iniţiativa „17+1" va influența unitatea politică a UE și dinamica reformelor din Balcanii de Vest, în contextul în care mai multe țări europene au exprimat poziții diplomatice favorabile Beijingului, în detrimentul intereselor politice comunitare (disputele din Marea Chinei de Sud, drepturile minorităților). ${ }^{40}$ Drept urmare, UE a insistat asupra evaluării oricărui acord bilateral cu China pentru a se asigura că sunt respectate legislația și politicile europene ${ }^{41}$ și a propus o nouă agendă strategică de cooperare pentru a-și consolida relațiile cu această țară. ${ }^{42}$

În același timp, au existat dezbateri cu privire la strategia Chinei de a oferi o linie de credit de 10 miliarde de euro pentru investiții, situație care a fost asociată cu așa-numita diplomație a prinderii în capcana îndatorării (debt-trap diplomacy), aplicată de autoritățile de la Beijing în Africa sau Asia. ${ }^{43} \mathrm{Au}$ fost ridicate semne de întrebare cu privire la sustenabilitatea investițiilor chinezești și la modul în care China va profita de vulnerabilitatea economiilor europene pentru a-și asigura accesul la anumite obiective strategice. Conform studiilor existente, toate statele membre ale Inițiativei „17+1” sunt expuse pericolului îndatorării, în eventualitatea unor împrumuturi excesive. ${ }^{44}$

\footnotetext{
${ }^{39}$ Andreea Budeanu, The "16+1" Platform: China's Opportunities for Central and Eastern Europe, Asia Focus \#86, Institut de Relations Internationales et Stratégiques, octombrie 2018, p. 4; Mihai Varga, „The return of economic nationalism to East Central Europe: Right-wing intellectual milieus and anti-liberal resentment", în Nations and Nationalism, vol. 27, nr. 1, Association for the Study of Ethnicity and Nationalism, ianuarie 2021, pp. 208 și 214.

${ }^{40}$ Gisela Grieger, China, the $16+1$ format and the EU, European Parliamentary Research Service, septembrie 2018, pp. 2-3.

$41 * * *$, State of EU-China relations, European Parliament resolution, 12 September 2018, p. 1.

$42 * * *$, Elements for a new EU strategy on China, Joint Communication to the Parliament and the Council, Brussels, 22 June 2016, pp. 1 şi 4-5.

${ }^{43}$ Jeremy Garlick, op. cit., 2019, p. 16.

${ }^{44}$ John Hurley, Scott Morris, Gailyn Portelance, ,Examining the debt implications of the Belt and Road Initiative from a policy perspective", în Journal of Infrastructure, Policy and Development, vol. 3, nr. 1, 2019, pp. 141 şi 146; Henrik Larsen, The Western Balkans between the EU, NATO, Russia and China, CSS Analyses in Security Policy, nr. 263, Zurich, 2020, p. 3.
} 
$\mathrm{Cu}$ toate acestea, există suficiente date care indică faptul că eforturile economice ale Chinei nu ar genera în mod necesar instabilitate politico-militară în CEE. În primul rând, povestea economică a Iniţiativei „,17+1" este departe de a fi un succes. Deși guvernul chinez a lăudat și a promovat acest proiect, rezultatele economice au rămas modeste în comparație cu cele din alte regiuni, precum Africa sau chiar Europa de Vest. ${ }^{45}$ Dovezi empirice au arătat că investițiile străine directe ale Chinei nu au crescut semnificativ de la lansarea proiectului. Modul de implementare a Iniţiativei a fost, la rândul său, criticat, fiind subliniată lipsa unor politici coordonate care să conveargă către obiective concrete. De exemplu, în România niciun proiect nu a fost implementat până acum, în pofida numeroaselor discuții purtate între cele două guverne.$^{46}$ Situația este similară în Serbia, unde modernizarea căii ferate dintre Belgrad și Budapesta se află în faza inițială, deși a fost anunțată încă din anul $2015 .{ }^{47}$ Nemulțumiri cu privire la lipsa investițiilor relevante au apărut și din partea principalilor susținători ai proiectului, Polonia, Cehia și Ungaria. ${ }^{48}$ Astfel, iniţiativa a oferit mai degrabă impresia unei platforme politice și diplomatice decât cea a unui plan regional capabil să stimuleze cooperarea economică.

În al doilea rând, deși consolidarea legăturilor economice ar fi trebuit să atenueze pozițiile politice ale guvernelor europene, atitudinea lor a devenit mult mai reticentă în ceea ce privește viitorul acestui proiect. Ca atare, la cel mai recent summit (februarie 2021) nu mai puțin de șase țări nu au fost reprezentate la cel mai înalt nivel (președinte sau premier), ci au preferat să delege responsabilitățile miniștrilor. ${ }^{49}$ Mesajul a fost destul de clar având în vedere cât de mult accent pun liderii chinezi pe protocoalele diplomatice, atitudinea statelor respective ilustrând importanța pe care o acordă umbrelei de securitate NATO. Pentru statele baltice, Alianța Nord-Atlantică reprezintă o garanție a securității în fața Rusiei, în timp ce România și Polonia formează „stâlpii” scutului de apărare antirachetă al NATO.

În al treilea rând, proiectul Huawei de infrastructură $5 \mathrm{G}$ propus de China, față de care SUA și-au exprimat cele mai mari îngrijorări, pare să fi ajuns într-un impas. Inițial, se părea că acesta va umbri celelalte mișcări economice ale Beijingului, datorită potențialului său de a pătrunde în rețelele digitale esențiale pentru

\footnotetext{
${ }^{45}$ Andreea Budeanu, op. cit., octombrie 2018, p. 7.

${ }^{46}$ Ibidem, p. 10.

${ }^{47}$ Samuel Rogers, „China, Hungary, and the Belgrade-Budapest Railway Upgrade: New PoliticallyInduced Dimensions of FDI and the Trajectory of Hungarian Economic Development", în Journal of East-West Business, vol. 25, nr. 1, 2019, pp. 93-94.

${ }^{48}$ Jeremy Garlick, op. cit., 2019, pp. 3 și 17.

${ }^{49}$ Stuart Lau, „China's Eastern Europe Strategy gets the cold shoulder”, Politico, 9 februarie 2021, URL: https://www.politico.eu/article/china-xi-jinping-eastern-europe-trade-agriculture-strategy-getsthe-cold-shoulder, accesat la 28.02.2021.
} 
funcționarea NATO.$^{50} \mathrm{Cu}$ toate acestea, ultimele evoluții au arătat o reticență a statelor din Europa central-estică față de intrarea Chinei în rețeaua europeană $5 \mathrm{G}$ și față de accesul acesteia la infrastructura digitală de pe întregul continent. Aproape toți membrii „,17+1” (exceptând Bosnia și Herzegovina, Croația, Ungaria și Muntenegru) au semnat acorduri cu SUA sau și-au declarat intenția de a se alătura programului $5 G$ Clean Network demarat de guvernul american. Acest proiect își propune să limiteze accesul la piața euroatlantică pentru companiile chinezești care nu respectă regulile occidentale referitoare la transmiterea și protecția datelor sau securitatea cibernetică. ${ }^{51}$ Inițiativa a fost salutată de secretarul general adjunct al NATO, Mircea Geoană, care a subliniat importanța strategică a unei rețele digitale securizate. ${ }^{52}$

Un alt factor care trebuie menționat este că Inițiativa „17+1" nu a atras atenția Alianței Nord-Atlantice în ceea ce privește securitatea flancului său estic. Deși China își propune să dezvolte o sferă de influență prin abordarea obiectivelor strategice, precum $h u b$-urile de transport, liderii NATO se îndoiesc că această Inițiativă va avea un impact semnificativ asupra securității regionale. De asemenea, ei cred că implicarea companiilor chinezești este destul de modestă şi nu poate fi folosită ca instrument politico-militar împotriva NATO. China este văzută, mai degrabă, ca un amalgam de oportunități și amenințări care pot fi gestionate printr-o abordare responsabilă. ${ }^{53} \mathrm{Ca}$ atare, nu a existat nicio poziție oficială a Alianței cu privire la inițiativa chineză. Potrivit secretarului general al NATO, Jens Stoltenberg, China nu constituie o amenințare militară directă în acest moment și este puțin probabil ca acest aspect să se modifice în curând. În opinia sa, Rusia va reprezenta principala amenințare pentru flancul estic în următorul deceniu și, de aceea, Alianța ar trebui să se concentreze asupra gestionării ameninţărilor asimetrice ale Moscovei. ${ }^{54}$

Toate aceste aspecte întăresc percepția generală cu privire la utilitatea și evoluția Iniţiativei „17+1”, care tinde să rămână un proiect ambițios la nivel declarativ, concretizat în principal prin forumuri și programe de schimb. Prin urmare, viitorul politic al proiectului este unul incert.

\footnotetext{
${ }^{50}$ Andrew A. Michta, China in Europe and Transatlantic Security, International Centre for Defence and Security, Tallinn, 2020, p. 1; Francois Heisbourg, ,NATO 4.0: The Atlantic Alliance and the Rise of China”, în Survival, vol. 62, nr. 2, 2020, pp. 96 și 99.

${ }^{51}$ Andreea Brînză, „How China's 17+1 Became a Zombie Mechanism”, The Diplomat, 10 februarie 2021, URL: https://thediplomat.com/2021/02/how-chinas-171-became-a-zombie-mechanism, accesat la 28.02.2021.

52 ***, Remarks by NATO Deputy Secretary General Mircea Geoană at the Brussels Forum, NATO, 29 iunie 2020, URL: https://www.nato.int/cps/en/natohq/opinions_176949.htm, accesat la 28.02.2021. $53 * * *$, NATO 2030: United for a New Era, Analysis and Recommendations of the Reflection Group Appointed by the NATO Secretary General, 25 noiembrie 2020, pp. 27-28.

54 ***, Remarks by NATO Secretary General Jens Stoltenberg on launching \#NATO2030 Strengthening the Alliance in an increasingly competitive world, NATO, 8 iunie 2020, URL: https:// www.nato.int/cps/en/natohq/opinions_176197.htm, accesat la 02.03.2021.
} 


\section{Concluzii}

Prezentul studiu a oferit o evaluare a diplomației economice chineze din Europa Centrală și de Est și a implicațiilor geopolitice pentru flancul estic al NATO. Conștientă de atuurile financiare și de necesitatea investițiilor străine în regiune, China a lansat Inițiativa „17+1” pentru a-și facilita accesul pe piețele emergente din CEE. Proiectul a fost promovat sub forma unor fluxuri financiare direcționate de China către aceste țări, care urmau să fie folosite pentru dezvoltarea infrastructurii și a schimburilor comerciale. Configurația sa a cuprins majoritatea statelor din fostul bloc sovietic, fiind perceput de o parte însemnată a mediului academic și a elitelor politice europene mai degrabă ca o modalitate prin care China să își extindă influența politică, decât ca un demers economic. Opiniile acestora s-au concentrat în jurul ideii potrivit căreia guvernul chinez încearcă să speculeze oportunități strategice de reînnoire a legăturilor istorice cu regiunea CEE, provocând temeri la nivelul UE.

În pofida optimismului inițial al membrilor săi, Inițiativa „17+1" nu s-a bucurat de succesul așteptat. Investițiile chineze au fost modeste, iar majoritatea proiectelor de anvergură nu au fost implementate, existând carențe vizibile în coordonarea lor. Drept urmare, încrederea membrilor în viitorul Iniţiativei a scăzut considerabil, aspect confirmat de interesul scăzut pe care liderii europeni 1-au afișat cu ocazia ultimului summit. Lipsa de orizont a proiectului a fost remarcată și de liderii NATO, care au considerat suficientă perpetuarea unor relații cordiale cu China, pentru a menține actualul climat de securitate în flancul său estic.

De cealaltă parte, statul chinez a păstrat o retorică optimistă vizavi de evoluția parteneriatelor sino-europene, insistând asupra unei cooperări de tip câștig-câștig, prin schimburi comerciale echitabile și câștiguri mutuale. Acest discurs trebuie privit, însă, dintr-o perspectivă de ansamblu, conturată în jurul ambițiilor geopolitice ale Chinei și pe care liderii săi încearcă să o expună sub forma unei puteri soft multifațetate.

\section{BIBLIOGRAFIE:}

1. ***, ,16+1” mechanism set to bolster China-Europe ties, Cooperation between China and Central and Eastern European Countries, 2018, URL: http:// www.china-ceec.org/eng/zdogjhz_1/t1575579.htm

2. ***, „Corruption Perceptions Index”, Transparency International, URL: https://www.transparency.org/en/cpi/2020/index/nzl

3. ***, Countries and regions: China, European Commission, 22 aprilie 2021, URL: https://ec.europa.eu/trade/policy/countries-and-regions/countries/china

4. ***, Elements for a new EU strategy on China, Joint Communication to the Parliament and the Council, Brussels, 22 iunie 2016. 
5. ***, Embassies of CEE Countries to China, Cooperation between China and Central and Eastern European Countries, 2021, URL: http://www.china-ceec.org/ eng/lj_5/zgzzdo16gsg/t1410687.htm

6. ***, „Full Text: Keynote Speech by Chinese President Xi Jinping at the China-CEEC Summit", în China Daily, 9 februarie 2021, URL: https://www. chinadaily.com.cn/a/202102/09/WS6022920ba31024ad0baa8699.html

7. ***, Introduction of the Secretariat for Cooperation between China and Central and Eastern European Countries, Cooperation between China and Central and Eastern European Countries, 2013, URL: http://www.china-ceec.org/eng/ msc_1/mscjj/t1411097.htm

8. ***, Remarks by NATO Secretary General Jens Stoltenberg on launching \#NATO2030 - Strengthening the Alliance in an increasingly competitive world, NATO, 8 iunie 2020, URL: https://www.nato.int/cps/en/natohq/opinions_176197.htm

9. ***, Remarks by NATO Deputy Secretary General Mircea Geoana at the Brussels Forum, NATO, 29 iunie 2020, URL: https://www.nato.int/cps/en/natohq/ opinions_176949.htm

10. ***, State of EU-China relations, European Parliament resolution, 12 septembrie 2018.

11. ANTONESCU, Mădălina Virginia, „The New Chinese Security Concept and the "Peaceful Rise of China" as two basic pillars of the contemporary Chinese Foreign Policy", în Polis, vol. 3, nr. 1(7), 2015.

12. BRÎNZĂ, Andreea, „How China's 17+1 Became a Zombie Mechanism”, The Diplomat, 10 februarie 2021, URL: https://thediplomat.com/2021/02/howchinas-171-became-a-zombie-mechanism

13. BUDEANU, Andreea, The "16+1" Platform: China's Opportunities for Central and Eastern Europe, Asia Focus \#86, Institut de Relations Internationales Et Strategiques, octombrie 2018.

14. DENG, Yong, „The New Hard Realities: 'Soft Power' and China in Transition”, în MINJIANG, Li (ed.), Soft Power: China's Emerging Strategy in International Politics, Lexington Books, Lanham, 2009.

15. FERGUSON, Niall, „Think Again: Power”, Foreign Policy, 3 noiembrie 2009, URL: https://foreignpolicy.com/2009/11/03/think-again-power/

16. FUCHS, Andreas, China's Economic Diplomacy and the Politics-Trade Nexus, Discussion Paper Series nr. 609, Alfred Weber Institute, University of Heidelberg, 2016.

17. GARLICK, Jeremy, „China's Economic Diplomacy in Central and Eastern Europe: A Case of Offensive Mercantilism?", în Europe-Asia Studies, vol. 71, nr. 8, 2019.

18. GLAWE, Linda; WAGNER, Helmut, The People's Republic of China in the middle-income trap?, Asian Development Bank Institute Working Paper, nr. 749, iunie 2017. 
19. GODEMENT, Francois; VASSELIER, Abigael, China at the Gates: A New Power Audit of EU-China Relations, European Council on Foreign Relations, London, 2017.

20. GRIEGER, Gisela, China, the 16+1 format and the EU, European Parliamentary Research Service, septembrie 2018.

21. HEATH, Timothy R., „China's Evolving Approach to Economic Diplomacy", în Asia Policy, vol. 22, 2016.

22. HEISBOURG, Francois, ,NATO 4.0: The Atlantic Alliance and the Rise of China", în Survival, vol. 62, nr. 2, 2020.

23. HILLMAN, Jonathan E.; MCCALPIN, Maesea, ,Will China's "16+1" Format Divide Europe?", Center for Strategic and International Studies, URL: https://www.csis.org/analysis/will-chinas-161-format-divide-europe, accesat la 26.02.2021.

24. HURLEY, John; MORRIS, Scott; PORTELANCE, Gailyn, „Examining the debt implications of the Belt and Road Initiative from a policy perspective", în Journal of Infrastructure, Policy and Development, vol. 3, nr. 1, 2019.

25. JIA, Ruixue Jia; KUDAMATSU, Masayuki; SEIM, David, „Political Selection in China: The Complementary Roles of Connections and Performance", în Journal of the European Economic Association, Vol. 13, nr. 4, august 2015.

26. LAI, Hongyi, „Introduction: the soft power concept and a rising China”, în LAI, Hongyi; LU, Yiji, China's Soft Power and International Relations, Routledge, New York, 2012.

27. LAI, Karen P. Y.; LIN, Shaun; SIDAWAY, James D., „Financing the Belt and Road Initiative (BRI): research agendas beyond the "dept-trap" discourse", în Eurasian Geography and Economics, vol. 61, nr. 2, 2020.

28. LARSEN, Henrik, The Western Balkans between the EU, NATO, Russia and China, CSS Analyses in Security Policy, nr. 263, Zurich, 2020.

29. LAU, Stuart, „China's Eastern Europe Strategy gets the cold shoulder”, Politico, 9 februarie 2021, URL: https://www.politico.eu/article/china-xi-jinpingeastern-europe-trade-agriculture-strategy-gets-the-cold-shoulder/, accesat la 28.02.2021.

30. LE CORRE, Philippe, „Chinese Investments in European Countries: Experiences and Lessons for the "Belt and Road" Initiative", în MAYER, Maximilian (ed.), Rethinking the Silk Road, Palgrave Macmilan, Singapore, 2018.

31. MCKENZIE, Baker, Belt \& Road: Opportunity \& Risk. The prospects and perils of China's New Silk Road, Silk Road Associates, 2017.

32. MEDEIROS, Evan, China's International Behavior: Activism, Opportunities, and Diversification, RAND Corporation, Santa Monica, 2009.

33. MICHITA, Andrew A., China in Europe and Transatlantic Security, International Centre for Defence and Security, Tallinn, 2020. 
34. MINGHAO, Zhao, „,The Belt and Road Initiative and its Implications for China-Europe Relations", în The International Spectator, vol. 51, nr. 4, 2016.

35. NORTH ATLANTIC TREATY ORGANIZATION, NATO 2030: Unified for a New Era, Analysis and Recommendations of the Reflection Group Appointed by the NATO Secretary General, 2020.

36. NYE, Joseph S., "The Changing Nature of World Power”, în Political Science Quarterly, vol. 195, nr. 2, vara 1990.

37. OHASHI, Hideo, „The Belt and Road Initiative (BRI) in the context of China's opening-up policy", în Journal of Contemporary East Asia Studies, vol. 7, nr. 2, 2019.

38. PEPERMANS, Astrid, „China's $16+1$ and Belt and Road Initiative in Central and Eastern Europe: economic and political influence at a cheap price", în Journal of Contemporary Central and Eastern Europe, vol. 26, nr. 2-3, 2018.

39. ROGERS, Samuel, „China, Hungary, and the Belgrade-Budapest Railway Upgrade: New Politically-Induced Dimensions of FDI and the Trajectory of Hungarian Economic Development", în Journal of East-West Business, vol. 25, nr. 1, 2019.

40. SHAMBAUGH, David, „China's Soft-Power Push: The Search for Respect", în Foreign Affairs, vol. 94, nr. 4, 2015.

41. STANZEL, Angela, China's Investment in Influence: The Future of 16+1 Cooperation, European Council on Foreign Relations, Londra, 2016.

42. TURCSANYI, Richard Q.; KACHLIKOVA, Eva, „The BRI and China's Soft Power in Europe: Why Chinese Narratives (Initially) Won", în Journal of Current Chinese Affairs, vol, 49, nr. 1, 2020.

43. VARGA, Mihai, „The return of economic nationalism to East Central Europe: Right-wing intellectual milieus and anti-liberal resentment", în Nations and Nationalism, vol. 27, nr. 1, Association for the Study of Ethnicity and Nationalism, ianuarie 2010.

44. WANG, Yiwei, „Public Diplomacy and the Rise of Chinese Soft Power,” în The Annals of the American Academy of Political and Social Science, vol. 616, 2008.

45. WILSON, Ernest J., „Hard Power, Soft Power, Smart Power”, în The Annals of the American Academy of Political and Social Science, vol. 616, 2008.

46. YAO, Yang, ,Chinese Approach to Economic Diplomacy”, în IKENBERRY, John G.; JISI, Wang; FENG, Zhu, America, China and the Struggle for World Order: Ideas, Traditions, Historical Legacies, and Global Visions, Palgrave Macmillan, New York, 2015.

47. YILDIRIM, Nilgün Eliküçük; ALAN, Mesut, „China’s Charm Defensive: Image Protection by Acquiring Mass Entertainment", în Pacific Focus, vol. XXXV, nr. 1, 2020.

48. ZHANG, Shuxiu, Chinese Economic Diplomacy: Decision-making actors and processes, Routledge, New York, 2016. 